\title{
Production of enzymatic complex from agro-industrial biomass and its application in combustible ethanol
}

\author{
Produção de complexo enzimático a partir de biomassa agroindustrial e sua aplicação em etanol \\ combustível \\ Producción de complejo enzimático a partir de biomasa agroindustrial y su aplicación en etanol \\ combustible
}

Received: 03/09/2021 | Reviewed: 05/13/2021 | Accept: 05/17/2021 | Published: 06/04/2021

\author{
Adam Gonçalves Arruda \\ ORCID: https://orcid.org/0000-0002-2956-1691 \\ Federal University of Uberlândia, Brazil \\ E-mail: adam.arruda@outlook.com \\ Igor Vieira Evangelista \\ ORCID: https://orcid.org/0000-0002-2864-441X \\ Federal University of Uberlândia, Brazil \\ E-mail: igorevangelista_vieira@ hotmail.com \\ Larissa Soares de Menezes \\ ORCID: https://orcid.org/0000-0002-7179-777X \\ Federal University of Uberlândia, Brazil \\ E-mail: larissasoaresmenezes@hotmail.com \\ Janaína Fischer \\ ORCID: https://orcid.org/0000-0002-7563-4097 \\ University of Passo Fundo, Brazil \\ E-mail: janaffischer@hotmail.com \\ Vicelma Luiz Cardoso \\ ORCID: https://orcid.org/0000-0002-8278-6988 \\ Federal University of Uberlândia, Brazil \\ E-mail: vicelma@ufu.br \\ Líbia Diniz Santos \\ ORCID: https://orcid.org/0000-0002-7128-5280 \\ Federal University of Uberlândia, Brazil \\ E-mail: libia@ufu.br \\ Carla Zanella Guidini \\ ORCID: https://orcid.org/0000-0002-6562-8160 \\ Federal University of Uberlândia, Brazil \\ E-mail: carlazguidini@ufu.br
}

\begin{abstract}
Waste biomass and agro-industrial by-products, for production ethanol, will meet much of the great demand for this product. To reduce costs and optimize production, this study investigated solid-state fermentation (SSF) to obtain crude enzyme complex (CEC) from different agro-industrial biomasses (sugarcane bagasse, corn peel bran, rice straw bran and roasting and ground coffee residue) using cellulolytic fungi. The most promising CEC were evaluated in simultaneous hydrolysis and fermentation (SHF) for ethanol production by Saccharomyces cerevisiae in a culture broth containing sugarcane bagasse treated by steam explosion, and roast and ground coffee residue. In SSF with bioreactor volume of $0.25 \mathrm{~L}$, containing $40 \mathrm{~g}$ of the biomass mixture and $40 \mathrm{~g}$ of sterile water with resuspended cells $\left(1.0 \times 10^{8}\right.$ spores/g of solid medium) and temperature of $30 \pm 2{ }^{\circ} \mathrm{C}$, the strains Trichoderma reesei and Penicilium oxalicum provided the best enzyme activity. The CEC of $T$. reesei provided a concentration of $7.5 \mathrm{~g} \mathrm{~L}^{-1}$ of ethanol in a substrate containing treated sugarcane bagasse $(60 \%)$ and roast and ground coffee residue $(40 \%)$, under SHF conditions ( $\mathrm{pH} 4.5,35 \pm 2{ }^{\circ} \mathrm{C}, 48 \mathrm{~h}$ ). The results obtained in this study show a promising alternative for correct disposal and use of residues and agro-industrial by-products by use in the production of enzymes and lignocellulosic ethanol.
\end{abstract}

Keywords: Ethanol; Residues; Enzyme complex; Lignocellulosic; Biomasses.

\section{Resumo}

Os resíduos de biomassa e subprodutos agroindustriais, utilizados para a produção de etanol, atenderá boa parte da grande demanda por esse produto. Para reduzir custos e otimizar a produção, este estudo investigou a fermentação em estado sólido (FES) para obter complexo enzimático bruto (CEB) de diferentes biomassas agroindustriais (bagaço de 
cana-de-açúcar, farelo de casca de milho, farelo de palha de arroz e torrefação e resíduo de café moído) usando fungos celulolíticos. Os CEB mais promissores foram avaliados em hidrólise e fermentação simultâneas (HFS) para produção de etanol por Saccharomyces cerevisiae em caldo de cultura contendo bagaço de cana tratado por explosão a vapor e resíduo de café torrado e moído. Em FES, com volume de biorreator de 0,25 L, contendo 40g da mistura de biomassa e $40 \mathrm{~g}$ de água estéril com células ressuspensas $\left(1,0 \times 10^{8}\right.$ esporos/g de meio sólido) e temperatura de $30 \pm 2^{\circ} \mathrm{C}$, as cepas Trichoderma reesei e Penicilium oxalicum forneceram a melhor atividade enzimática. A CEB de T. reesei proporcionou concentração de 7,5 $\mathrm{g} \mathrm{L}^{-1}$ de etanol em substrato contendo bagaço de cana tratado (60\%) e resíduo de café torrado e moído (40\%), nas condições HFS ( $\left.\mathrm{pH} 4,5 ; 35 \pm 2^{\circ} \mathrm{C} ; 48 \mathrm{~h}\right)$. Os resultados obtidos neste estudo mostraram uma alternativa promissora para a correta destinação e aproveitamento de resíduos e subprodutos agroindustriais para a produção de enzimas e etanol lignocelulósico.

Palavras-chave: Etanol; Resíduos; Complexo enzimático; Lignocelulósico; Biomassas.

\section{Resumen}

Los residuos de biomasa y los subproductos agroindustriales, utilizados para la producción de etanol, cubrirán gran parte de la gran demanda de este producto. Para reducir costos y optimizar la producción, este estudio investigó la fermentación en estado sólido (FES) para obtener complejo enzimático crudo (CEC) a partir de diferentes biomasas agroindustriales (bagazo de caña de azúcar, salvado de cáscara de maíz, salvado de paja de arroz y residuos de café tostado y molido) utilizando hongos celulolíticos. Los CEC más prometedores fueron evaluados en hidrólisis y fermentación simultáneas (HFS) para la producción de etanol por Saccharomyces cerevisiae en caldo de cultivo que contiene bagazo de caña de azúcar tratado por explosión de vapor y residuos de café tostado y molido. En FES, con un volumen de $0.25 \mathrm{~L}$ biorreactor, conteniendo $40 \mathrm{~g}$ de la mezcla de biomasa y $40 \mathrm{~g}$ de agua estéril con células resuspendidas $\left(1.0 \times 10^{8}\right.$ esporas/g de medio sólido) y temperatura de $30 \pm 2^{\circ} \mathrm{C}$, las cepas de Trichoderma reesei y Penicilium oxalicum aportaron la mejor actividad enzimática. El CEC de T.reesei proporcionó una concentración de $7.5 \mathrm{~g} \mathrm{~L}^{-1}$ de etanol en un sustrato que contenía bagazo de caña de azúcar tratado $(60 \%)$ y residuo de café tostado y molido (40\%), en condiciones HFS ( $\mathrm{pH} 4.5 ; 35 \pm 2{ }^{\circ} \mathrm{C} ; 48 \mathrm{~h}$ ). Los resultados obtenidos en este estudio mostraron una alternativa prometedora para el correcto destino y uso de residuos y subproductos agroindustriales para la producción de enzimas y etanol lignocelulósico.

Palabras clave: Etanol; Residuos, Complejo enzimático; Lignocelulósico; Biomasas.

\section{Introduction}

Lignocellulosic biomasses are renewable and sustainable raw materials used to produce bioethanol. Abundant in the form of residues from energy crops and agro-industrial products as well as food processing residues, they present themselves as an alternative to mitigate environmental impacts associated with energy demands, and uncertainties in relation to oil supply. Due to their recalcitrant structure, the steps for converting lignocellulosic materials are physical or thermochemical pretreatment, followed by some method to improve the accessibility and reactivity of carbohydrates, enzymatic hydrolysis for generation of fermentable sugars, and microbial fermentation to obtain fuel ethanol (Althuri et al., 2017; Li et al.; 2019; Robak and Balcerek, 2020).

Enzymatic hydrolysis is worthy of attention given the amount and cost of enzymes, complexity of biomass, and chemical reactions with generation of inhibitors (Khare et al., 2015; Nguyen et al., 2017). Efforts have been made to improve processes that aim for the viability of cellulosic ethanol. Thus, enzymatic preparations in situ (Fischer et al., 2017; Lopes et al., 2017; Wang et al., 2020) and the simultaneous hydrolysis and fermentation processes represent a strategy to decrease operating costs, reduce inhibition and contamination, and facilitate recovery of the final product (Öhgren et al., 2007; Leduc et al., 2010; Gu et al., 2014; Guidini et al., 2014; Cuevas et al., 2015).

Research regarding isolation and identification of microorganisms capable of growing on the surface of solid materials and generating cellulolytic enzymes is also worth mentioning. The solid-state fermentation process can be modified by varying the amount and composition of carbon sources and by adding nutrients and water to regulate activity during fermentation. The advantages are the use of agro-industrial waste as an energy source for microorganisms, facility of production and smaller generation of effluents (Dashtban et al., 2009; Lever et al., 2010; Liu et al., 2020; Singhania et al., 2008).

The present study evaluated the production of enzymatic complex by fermentation in solid state from different agroindustrial biomasses and fungi. Crude enzymatic complexes of fungi with the potential to produce cellulase were used to obtain 
ethanol from Saccharomyces cerevisiae in a culture broth containing sugarcane bagasse treated to steam explosion, roast residue and coffee grounds.

\section{Material and Methods}

Pereira et al. (2018) provides methodological support for present of research. Thus, the materials and methods used in this study are detailed in the next items.

\subsection{Microorganism and biomass}

Strains of fungi with the potential to produce an enzyme complex from different biomasses were obtained from the stock collection of the Biochemical Engineering Laboratory of the Faculty of Chemical Engineering, Federal University of Uberlândia. Saccharomyces cerevisiae Y904 used for alcoholic fermentation was obtained from AB Brazil (Pederneiras/SP, Brazil). Fungi were kept in Potato Dextrose Agar (PDA), with composition (in $\mathrm{g} \mathrm{L}^{-1}$ of $200.0 \mathrm{~g}$ of potato, $20.0 \mathrm{~g}$ glucose $\left(\mathrm{C}_{6} \mathrm{H}_{12} \mathrm{O}_{6}\right)$ and $20.0 \mathrm{~g}$ agar, stored in refrigeration temperature $\left(5 \pm 1{ }^{\circ} \mathrm{C}\right)$ and recultivated every 20 days. Saccharomyces cerevisiae was used in lyophilized form and stored at $5 \pm 1{ }^{\circ} \mathrm{C}$ during the study period.

Used biomasses were kindly supplied by the Sugarcane Technology Center (STC) and by cereal and food processing industries. Sugarcane bagasse, with low severity steam explosion treatment $\left(12 \mathrm{kgf} / \mathrm{cm}^{2}\right.$ for 8 minutes) (STC/Piracicaba - SP, Brazil). Rice straw bran (COCAL Cereais, Uberlândia-MG, Brazil); corn peel bran (Cargill, Uberlândia-MG, Brazil) roasting and grinding coffee (GeoCoffee, Patrocínio-MG, Brazil). Biomasses used in the experiments were stored at a temperature of 5 $\pm 1{ }^{\circ} \mathrm{C}$, and subsequently ground and sieved ( $1.8 \mathrm{~mm}$ mesh) before experiments. Corn peel bran was gelatinized (solid water ratio $1: 1,90^{\circ} \mathrm{C}, 15 \mathrm{~min}$ ) (Maarel et al., 2002).

\subsection{Selection of microorganisms}

Microorganisms listed in the Table 1 were evaluated and selected by enzymatic activity based on filter paper cellulase (Fpase) of the enzymatic complexes produced by Solid State Fermentation (SSF). Conditions were according to Fischer et al. (2014): $72 \mathrm{~h}$ fermentation time, $40 \mathrm{~g}$ solid substrate (60\% rice straw bran and $40 \%$ treated sugarcane bagasse), and $40 \mathrm{~g}$ water with resuspended cells of the selected microorganism.

Table 1 - Species of microorganisms evaluated to produce enzyme complex.

\begin{tabular}{cl}
\hline Identification & \multicolumn{1}{c}{ Microorganism species } \\
\hline A & Aspergillus ochraceus \\
B & Fusarium sp. \\
C & Monilia sitophila \\
D & Mucor racemosus Fresenius \\
E & Penicillium oxalicum \\
F & Trichoderma asperellum \\
G & Trichoderma harzianum \\
H & Trichoderma reesei \\
\hline
\end{tabular}

Source: Authors. 


\subsection{Production of crude enzymatic complex}

For cell growth, microorganism cells were produced by submerged fermentation, at $30 \pm 2{ }^{\circ} \mathrm{C}$ in flasks under agitation on a shaker at $150 \mathrm{rpm}$. We used Czapeck medium with the following composition $(\mathrm{g} / \mathrm{L}): 2 \mathrm{~g}$ sodium nitrate $\left(\mathrm{NaNO}_{3}\right), 1 \mathrm{~g}$ dibasic potassium phosphate $\left(\mathrm{K}_{2} \mathrm{HPO}_{4}\right), 0.5 \mathrm{~g}$ magnesium sulfate $\left(\mathrm{MgSO}_{4}\right), 0.5 \mathrm{~g}$ potassium chloride $(\mathrm{KCl}), 0.01 \mathrm{~g}$ iron II sulfate $\left(\mathrm{FeSO}_{4}\right)$ and $20 \mathrm{~g}$ glucose $\left(\mathrm{C}_{6} \mathrm{H}_{12} \mathrm{O}_{6}\right)$. After 48 hours, cells were centrifuged at $8000 \mathrm{~g}$ for 10 minutes, and washed twice with sterile water, resuspended in $40 \mathrm{~g}$ of sterile water and used in SSF $\left(1.0 \times 10^{8}\right.$ spores/g of solid medium).

For enzyme production, SSF was conducted in a static reactor with $0.25 \mathrm{~L}$ capacity and controlled temperature of $30 \pm 2{ }^{\circ} \mathrm{C}$, containing $40 \mathrm{~g}$ of previously sterilized solid medium, and $40 \mathrm{~g}$ of sterile water containing cells of one of the studied microorganisms. The composition of the solid medium was defined for each experiment. For the production of Crude Enzyme Complex (CEC) to extract enzymes, aqueous solution of Tween 80 in a concentration of $1.0 \%(\mathrm{v} / \mathrm{v})$ was used. The solution was submitted to stirring for 10 minutes $(100 \mathrm{rpm})$ followed by filtration to remove solid material and completed with sterile water to obtain $100 \mathrm{~mL}$ of CEC (liquid fraction).

\subsection{Evaluation of the SSF solid medium composition}

After selection of the most promising fungi for the production of enzyme complex, the composition of a suitable substrate for SSF was evaluated. SSF were performed with $40 \mathrm{~g}$ of solid medium (biomass). Composition is presented in Table 2 , and conditions are as previously mentioned for the production of crude enzymatic complex.

Table 2 - Composition of solid medium of SSF.

\begin{tabular}{ccccc}
\hline Composition & SB & CPB & RSB & RGCR \\
\hline Medium 1 & $40 \%$ & $60 \%$ & - & - \\
Medium 2 & $40 \%$ & - & $60 \%$ & - \\
Medium 3 & $40 \%$ & - & - & $60 \%$ \\
Medium 4 & $40 \%$ & $30 \%$ & $30 \%$ & - \\
Medium 5 & $40 \%$ & $30 \%$ & - & $30 \%$ \\
Medium 6 & $40 \%$ & $30 \%$ & $15 \%$ & $15 \%$ \\
\hline
\end{tabular}

Abbreviations: aSB: sugarcane bagasse with steam explosion treated $\left(12 \mathrm{kgf} / \mathrm{cm}^{2}, 8\right.$ minutes $) .{ }^{\mathrm{b}} \mathrm{CPB}$ : corn peel bran (gelatinized). ${ }^{\mathrm{C} S \mathrm{R}}$ : rice straw bran. ${ }^{\mathrm{d}} \mathrm{RGCR}$ : roasting and ground coffee residue. Source: Authors.

\subsection{SSF time evaluation}

SSF times were evaluated to maximize enzymatic activity. For the experiments, SSF times varied in 12-hour intervals (36, 48, 60, 72, 84, 96, 108 and 120 hours), using each of the selected fungi and respective solid medium composition. Other conditions were as described in the production of crude enzymatic complex section.

\subsection{Simultaneous enzyme hydrolysis and alcoholic fermentation}

Simultaneous enzymatic hydrolysis and alcoholic fermentation (SHF) processes were used. Enzymatic complexes were produced in situ by $T$. reesei and $P$. oxalicum for $72 \mathrm{~h}$. SHF was performed in a conical reactor with $0.25 \mathrm{~L}$ capacity, operating in batch with agitation (120 rpm), and temperature of $35 \pm 2{ }^{\circ} \mathrm{C}$ for 48 hours. A total of $25 \mathrm{~g}$ of substrate was used, varying in composition and concentration of the SHF solid mediam, is shown in Table 3. The initial $\mathrm{pH}$ was 4.5 and the concentration was $30 \mathrm{~g} \mathrm{~L}^{-1}$ of S. cerevisiae Y904. The alcoholic fermentation medium was supplemented with the following composition ( $\mathrm{g}$ 
$\left.\mathrm{L}^{-1}\right): 5 \mathrm{~g}$ monobasic potassium phosphate $\left(\mathrm{KH}_{2} \mathrm{PO}_{4}\right), 5 \mathrm{~g}$ potassium chloride $(\mathrm{KCl}), 1 \mathrm{~g}$ magnesium sulfate $\left(\mathrm{MgSO}_{4}\right), 1 \mathrm{~g}$ ammonium chloride $\left(\mathrm{NH}_{4} \mathrm{Cl}\right)$ and $1 \mathrm{~g}$ yeast extract. Experiments were carried out in triplicate.

Table 3 - Composition of solid medium for alcoholic fermentation.

\begin{tabular}{ccc}
\hline Composition & SB & RGCR \\
\hline Medium 1 & $50 \%$ & $50 \%$ \\
Medium 2 & $60 \%$ & $40 \%$ \\
Medium 3 & $70 \%$ & $30 \%$ \\
\hline
\end{tabular}

Abbreviations: ${ }^{a} \mathrm{SB}:$ sugarcane bagasse with steam explosion treated (12 $\mathrm{kgf} / \mathrm{cm}^{2}, 8$ minutes). ${ }^{\mathrm{b}} \mathrm{RGCR}$ : roasting and ground coffee residue. Source: authors.

\subsection{Analytical methods}

SSF cell concentrations were determined in a Neubauer Chamber. Propagation plate methodology ( $48 \mathrm{~h}$ incubation at $40{ }^{\circ} \mathrm{C}$ in Czapek medium) (Fischer et al., 2017) was sued to start SSF by estimating the optical density at $600 \mathrm{~nm}$, correlated with the number of colonies obtained. The cellulase activity was determined by filter paper activity (FPA), following IUPAC standard procedures; result was expressed in international Units (Ghose, 1987). Sugar and ethanol concentrations were determined by high performance liquid chromatography (HPLC; Shimadzu LC-20A) equipped with a refractive index detector, a Hi-plex Ca column $\left(7.0 \times 300 \mathrm{~mm}\right.$, Agilent, Santa Clara, CA, USA), operated at $85{ }^{\circ} \mathrm{C}$ and ultra-pure water as the mobile phase at a flow rate of $0.6 \mathrm{~mL} / \mathrm{min}$.

\section{Results and Discussion}

\subsection{Selection of microorganisms producing enzyme complex}

The results of enzymatic activity (Fpase) of crude enzyme complexes (CEC) produced by different fungi studied are shown in Figure 1. All microorganisms were able to produce CEC under experimental conditions, ranging from 0.5 to 4.2 FPU/mL. 
Figure 1 - Activity of the enzymatic complex (FPU/mL) produced by different strains. (A) Aspergillus ochraceus, (B) Fusarium sp, (C) Monilia sitophila, (D) Mucor racemosus Fresenius, (E) Penicillium oxalicum, (F) Trichoderma asperellum, (G) Trichoderma harzianum, (H) Trichoderma reesei.

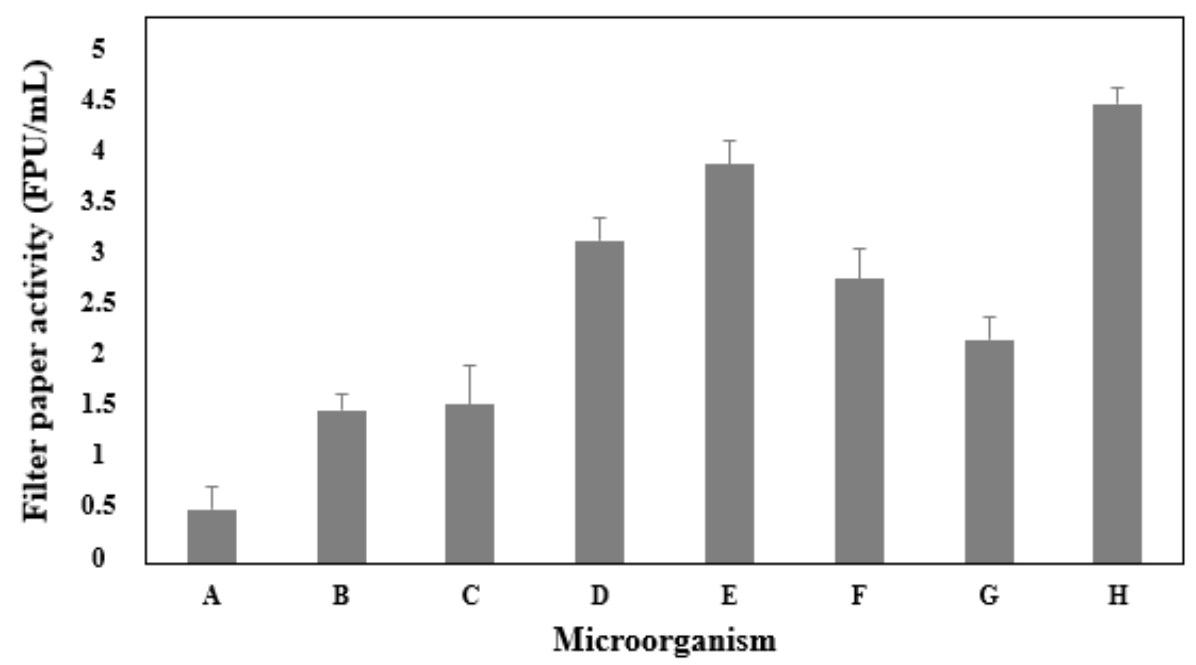

Fonte: Autores.

The strains Trichoderma reesei and Penicilium oxalicum showed higher performance. Thus, the two strains were selected for the next experiments. The observed higher performance corroborates with other researchers who report that species from the genera Trichoderma, Aspergillus, Penicillium, Chaetomium, Mucor and Clostridium, as well as other fungi, have the potential to produce enzymatic complexes used in the production of enzymes for hydrolysis of cellulosic biomass (Buzzini and Martini 2002; El-Said and Saleem 2008; Fischer et al., 2013; Rocha et al., 2013; Thomas et al., 2013; Althuri et al., 2017; Liu et al., 2020; Wang et al., 2020).

\subsection{Selection of solid-state fermentation medium for CEC production}

The solid materials used as substrate for SSF were composed of widely available agro-industrial by-products. All evaluated solid media were able to generate an enzyme complex from fungi, as shown in Figure 2. Medium 5 (40\% SB, 30\% CPB and 30\% RGCR) enabled the production of an enzyme complex with greater enzyme activity for the two evaluated strains (6.1 and 5.4 FPU/mL for T. reesei and P. oxalicum, respectively). 
Figure 2 - Effect of the composition of the solid medium on the enzymatic activity $\left(72 \mathrm{~h}, 30 \pm 2^{\circ} \mathrm{C}\right)$.

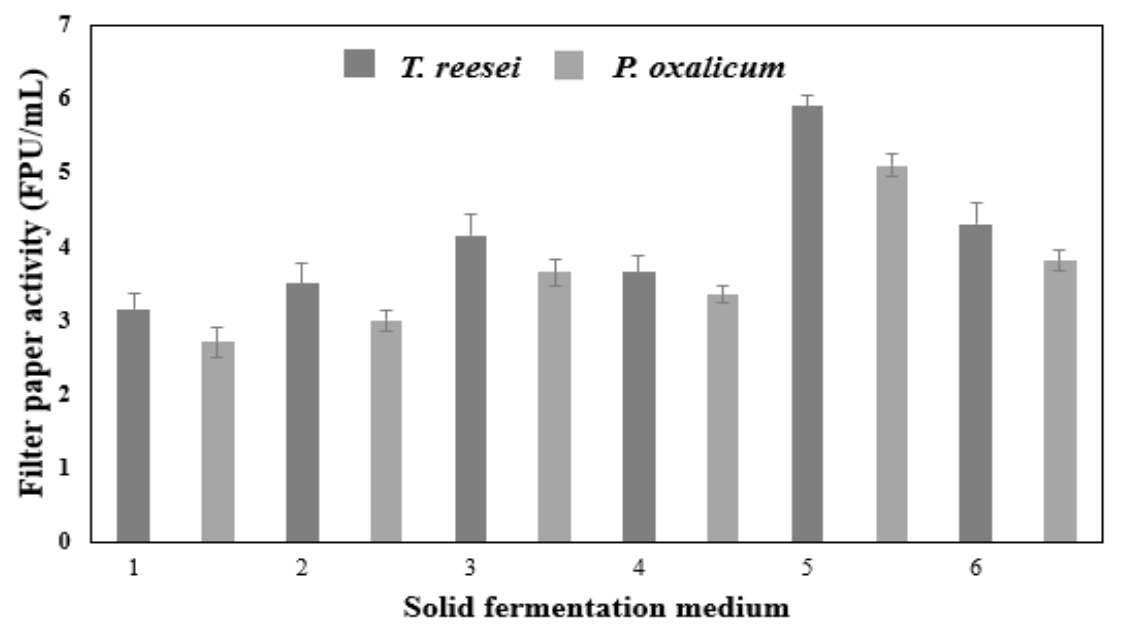

Fonte: Autores.

The sugarcane bagasse used contained about $50 \%$ water, $30 \%$ cellulose, $7.3 \%$ hemicellulose, $11.2 \%$ lignin and $1.5 \%$ ash, according to previous characterization (method according to Browning (1967). The use of biomass as a carbon source for cultivation of microorganisms in solid media and production of enzymes and biomass for cellulolytic ethanol have been highlighted in previous studies (Fischer et al., 2017; Lopes et al., 2017). The results obtained in the present study point to biomass, roasting and ground coffee residue (RGCR), still little used in technologies for obtaining cellulolytic enzymes and renewable energy. Also for biomass, corn peel bran (CPB), which has a high fiber, cellulose and hemicellulose content. It is also worth mentioning that Brazil is the world's largest producer of coffee, and one of the world's largest producers of corn, generating significant amounts of residue from processing these materials, so their use in biotechnological processes allows proper destination and recovery of these residues.

In a study by $\mathrm{Li}$ et al. (2019) duckweed as an inducer of cellulase production by Trichoderma reesei Rut C30, in a reaction induced with $50 \mathrm{~g} \mathrm{~L}^{-1}$ of duckweed in hake flasks, during $120 \mathrm{~h}$ the cultivation, the filter-paper activity (FPA) reached 6.5 FPU/mL for $72 \mathrm{~h}$ the cellulase production. And Wang et al. (2020) studied cellulase production by the new mutant strain Trichoderma harzianum EUA 20; it exhibited filter paper cellulase activity up to $14.79 \mathrm{IU} / \mathrm{mL}$ within 6 days in shake flask cultivation. Using pretreated oil palm empty fruit bunch and corncob powder as substrates, the presented activity was 6.52 and $8.80 \mathrm{IU} / \mathrm{mL}$, respectively. In a study by Sukumaran et al. (2009) cellulases from Trichoderma reesei Rut C30 demonstrated the best results in $96 \mathrm{~h}$ of SSF for cellulase $(1.14 \mathrm{FPU} / \mathrm{mL})$, wheat bran was used as substrate for production of the enzyme under solid state fermentation.

\subsection{Evaluation of solid state fermentation time in the production of CEC}

Figure 3 presents the results of the effect of fermentation time in solid state on enzymatic activity. The 72-hour time was the most suitable for both evaluated fungi, being 6.1 FPU/mL for T. reesei and 5.4 FPU/mL for P. oxalicum. The reduction in enzyme production after 72 hours may be due to formation of inhibitory metabolites in the medium. In this study, was fixed a period of $72 \mathrm{~h}$ for enzymatic complex production for hydrolysis and alcoholic fermentation. 
Figure 3 - Effect of FES time with enzyme activity (A) Trichoderma reesei (B) Penicillium oxalicum.

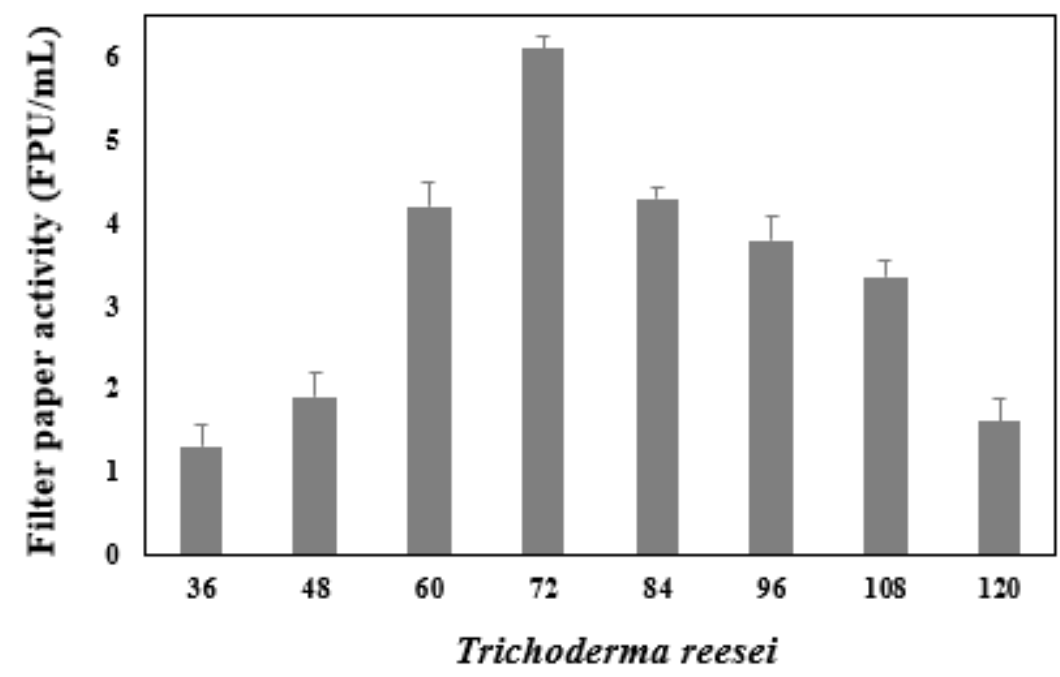

Solid state fermentation time (h)

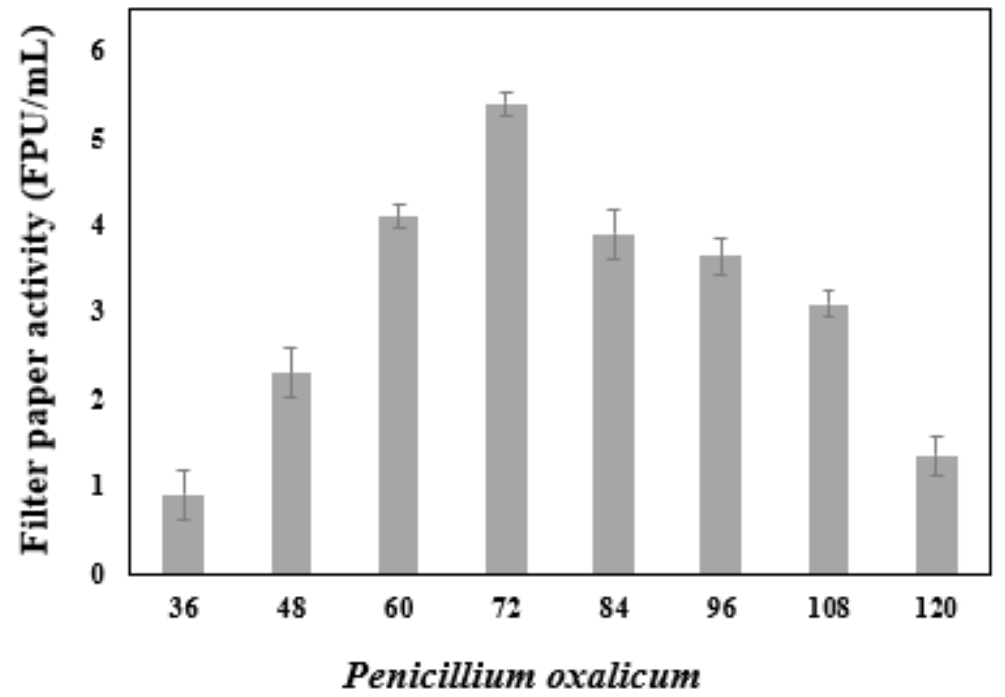

Solid state fermentation time (h)

Fonte: Autores.

The results corroborate with the studies by Li et al. (2019) who obtained 6.5 FPU/ $\mathrm{mL}$ of cellulase activity for $72 \mathrm{~h}$ of cultivation using T. reesei Rut C30. And they are superior to the results obtained by Sukumaran et al. (2009), that in $96 \mathrm{~h}$ of solid state fermentation obtained $1.14 \mathrm{FPU} / \mathrm{mL}$ of cellulase activity.

\subsection{Evaluation of ethanol production by varying the composition of the alcoholic fermentation medium}

Three different media were used during alcoholic fermentation for ethanol production: medium 1 (50\% SB and 50\% RGCR); medium 2 (60\% SB and 40\% RGCR) and medium 3 (70\% SB and 30\% RGCR) is shown in Table 4. 
Table 4 - Effect of solid medium on ethanol production by Saccharomyces cerevisiae ( $\left.\mathrm{pH} 4.5,35 \pm 2{ }^{\circ} \mathrm{C}, 48 \mathrm{~h}, \mathrm{SHF}\right)$.

\begin{tabular}{llll}
\hline \multirow{2}{*}{ Microorganism } & \multicolumn{2}{l}{ Medhanol production $\left(\mathrm{g} \mathrm{L}^{\mathbf{1}}\right)$} & Medium 3 \\
\hline Trichoderma reesei & $6.1 \pm 0.18$ & Medium 2 & $5.3 \pm 0.14$ \\
Penicillium oxalicum & $3.2 \pm 0.14$ & $7.5 \pm 0.11$ & $2.9 \pm 0.25$ \\
\hline
\end{tabular}

Abbreviations: ${ }^{a} \mathrm{SB}$ : sugarcane bagasse with steam explosion treated $\left(12 \mathrm{kgf} / \mathrm{cm}^{2}, 8\right.$ minutes $) .{ }^{\mathrm{b}} \mathrm{RGCR}$ : roasting and ground coffee residue.

Source: Authors.

The proportions of biomass 60\% BCA and $40 \%$ RC (Medium 2) provided the highest ethanol production for both strains used, indicating the potential of coffee residue as an additional biomass source for obtaining fuel ethanol. Using an enzyme complex of P. oxalicum and the medium 2 of SSF, $4.3 \mathrm{~g} \mathrm{~L}^{-1}$ of ethanol was obtained. Crude enzyme complex from $T$. reesei provided the most expressive concentration of ethanol, equal to $7.5 \mathrm{~g} \mathrm{~L}^{-1}$.

Improvements in ethanol yield can be obtained by studying the conditions of alcoholic fermentation. Fischer et al. (2017) obtained a concentration of $12.1 \mathrm{~g} \mathrm{~L}^{-1}$ under the optimized conditions of $36 \mathrm{~h}$ of SFS, temperature of $35{ }^{\circ} \mathrm{C}, 99.8 \%$ of enzymatic load, amount of inoculum of $29.5 \mathrm{~g} \mathrm{~L}^{-1}$ (S. cerevisiae) and concentration of $24.9 \%$ of sugarcane bagasse treated with steam explosion.

The authors Althuri et al. (2017) used a mixture of biomasses (Ricinus communis, Saccharum officinarum and Saccharum spontaneum) and concoction of laccase enzymes (Pleurotus djamor) and holocellulase (T. reesei RUT C30) followed by co-formation to produce bioethanol. In optimized condition (substrate loading of $27.54 \%(\mathrm{w} / \mathrm{v})$ and incubation time of $21.96 \mathrm{~h}$ ), the aforementioned authors obtained the maximum ethanol concentration of $7.86 \%(\mathrm{v} / \mathrm{v})\left(62.01 \mathrm{~g} \mathrm{~L}^{-1}\right)$. Lever et al. (2010) produced crude enzymatic extract by $T$. reesei (CBS439.92) and obtained 5 to $21 \mathrm{~g} \mathrm{~L}^{-1}$ of ethanol concentration in batch fermentation, and when they changed the form of conduction to fed-batch fermentation.

\section{Conclusion}

With the analysis of the results and discussions it can be noted that crude enzymatic complexes produced from solid state fermentation of a mixture of agro-industrial biomass and cellulolytic fungi are promising regarding the use of residues and agro-industrial by-products. Brazil has great potential for producing ethanol from biomass, mainly because it is one of the largest producers of sugarcane, corn and coffee. Improvements associated with ethanol production can be achieved by nutrient feeding strategies, concentration of enzyme complexes, enzyme concoctions and successive fermentations.

The study of the use of mixtures of enzymatic complexes obtained by the most promising microorganisms in the production of lignocellulosic enzymes and application in the production of ethanol is important for future research and work. Also the study of conditions optimized for simultaneous enzymatic hydrolysis and alcoholic fermentation such as enzyme load, amount of yeast inoculum, substrate concentration, and process temperature.

\section{Acknowledgments}

This study was supported by the Minas Gerais State Research Foundation, Brazil (FAPEMIG), under project code FAPEMIG (TEC- APQ- 02489-16 e TEC-APQ-02079-16). The authors are also gratefully to the Cane Technology Centre (CTC), Brazil, and cereal and food processing industries, Brazil. 


\section{References}

Althuri, A. Gujjala \& L. K. S., \& Rintu. B. (2017). Partially consolidated bioprocessing of mixed lignocellulosic feedstocks for ethanol production. Bioresource Technology. 245, 530-539.

Browning, B. L. (1967). Interscience Publishers.

Buzzini, P. \& Martini, A. (2002). Extracellular enzymatic activity profiles in yeast and yeast-like strains isolated from tropical environments. Journal Applied Microbiology. 93, 1020-1025.

Cuevas, M., Sanchez, S., Garcia, J. F., Baeza, J., Parra, C., \& Freer, J. (2015). Enhanced ethanol production by simultaneous saccharification and fermentation of pretreated olive stones. Renewable Energy. 74, 839-847.

Dashtban, M., Schraft, H., \& Qin, W. (2009). Fungal bioconversion of lignocellulosic residues; opportunities \& perspectives. International Journal of Biological Sciences. 6, 578-95.

El-Said, A., \& Saleem, A. (2008). Ecological and physiological studies on soil fungi at western region, Libya. Microbiology. 36, 1-9.

Fischer, J., Lopes, V. S., Coutinho Filho, U., \& Cardoso, V. L. (2017). Machine learning techniques applied to lignocellulosic ethanol in simultaneous hydrolysis and fermentation. Brazilian Journal of Chemical Engineering. 34, 53-63.

Fischer, J., Lopes, V. S., Galvão, C., Teodoro, J., Coutinho Filho, U., \& Cardoso, V. L. (2013). Utilization of Cheese Whey and Cellulosic Biomass for Production of Ethanol by Selected Fungi Strain from Brazilian Savannas. Chemical Engineering Transactions. 32, 1075-1080.

Fischer, J., Lopes, V. S., Queiroz, E. F., Coutinho Filho, U., \& Cardoso, V. L. (2014). Second generation ethanol production using crude enzyme complex produced by fungi collected in Brazilian Cerrado (Brazilian Savanna). Chemical Engineering Transactions. 38, 487-492.

Ghose, T. K. (1987). Measurement of cellulase activities. Pure and Applied Chemistry. 59, 257- 268.

Gu, H., Zhang J., \& Bao, J. (2014). Inhibitor analysis and adaptative evolution of Saccharomyces cerevisiae for simultaneous saccharification and ethanol fermentation from industrial waste corncob residues. Bioresource Technology. 157, 6-13.

Guidini, C. Z., Marquez, L. D. S., Silva, H. A., Resende, M. M., Cardoso, V. L., \& Ribeiro, E. J. (2014). Alcoholic Fermentation with Flocculant Saccharomyces cerevisiae in Fed-Batch Process. Applied Biochemistry and Biotechnology.172, 1623-1638.

Khare, S. K., Pandey, A., \& Larroche, C. (2015). Current perspectives in enzymatic saccharification of lignocellulosic biomass. Biochemical Engineering Journal. 102, 38-44.

Leduc, S., Starfelt, F., Dotzauer, E., Kindermann, G., McCallum I Obersteiner, M., \& Lundgren, J. (2010). Optimal location of lignocellulosic ethanol refineries with polygeneration in Sweden. Energy. 35, 2709-2716.

Lever, M., Ho, G., \& Cord-Ruwisch, R. (2010). Ethanol from lignocellulose using crude unprocessed cellulase from solid-state fermentation. Bioresource Technology. 101:7083-7087.

Li, C., Li, D., Feng, J., Fan, X., Chen, S., Zhang, D., \& He, R. (2019). Duckweed (Lemna minor) is a novel natural inducer of cellulase production in Trichoderma reesei. Journal of Bioscience Bioengineering. 127, 486-491.

Liu, L., Jiao, J., Fang, B., Lv. A., Ming, Y., Li, M., \& Salam, N. (2020). Isolation of Clostridium from Yunnan-Tibet hot springs and description of Clostridium thermarum sp. nov. with lignocellulosic ethanol production. Systematic and Applied Microbiology. 43, 126-104.

Lopes, V. S., Fischer, J., Pinheiro, T. M. A., Cabral, B. V., Cardoso, V. L., \& Coutinho Filho, U. (2017). Biosurfactant and ethanol co-production using Pseudomonas aeruginosa and Saccharomyces cerevisiae co-cultures and exploded sugarcane bagasse. Renewable Energy. 109, 305-310.

Maarel, M. J. E. C., Veen, B, Uitdehaag, J. C. M., Leemhuis, H., \& Dijkhuizen, L. (2002). Properties and Applications of Starch-converting Enzymes of the $\alpha$ amylase family. Journal Biotechnology. 94 137-155.

Nguyen, T. Y., Cai, C. M., Kumar, R., \& Wyman, C. E. (2017). Overcoming factors limiting high-solids fermentation of lignocellulosic biomass to ethanol. Proceedings of the National Academy of Sciences. 114, 11673-11678.

Öhgren, K., Bura, R., Lesnicki, G., Saddler, J., \& Zacchi, G. (2007). A comparison between simultaneous saccharification and fermentation and separate hydrolysis and fermentation using steam-pretreated corn stover. Process Biochemistry. 42, 834-839.

Pereira, A. S. et al. (2018). Metodologia da pesquisa cientifica. UFSM. https://repositorio.ufsm.br/bitstream/handle/1/15824/Lic_Computacao_MetodologiaPesquisa-Cientifica.pdf?sequence $=$.

Robak, k., \& Balcerek, M. (2020). Current state-of-the-art in ethanol production from lignocellulosic feedstocks. Microbiological Research. $240,126-534$.

Rocha, N. R. F. A., Barros, M. A., Fischer, J., Coutinho Filho, U., \& Cardoso, V. L. (2013). Ethanol production from agroindustrial biomass using a crude enzyme complex produced by Aspergillus niger. Renewable Energy. 57, 432-435.

Singhania, R. R., Patel, A. K., Soccol, C. R., Pandey, A. (2008). Recent advances in solid-state fermentation. Biochemical Engineering Journal. $4413-8$.

Sukumaran, R. K., Singhania, R. R., Mathew, G. M., \& Pandey, A. (2009). Cellulase production using biomass feed stock an its application in lignocelluloses saccharification for bio-ethanol production. Renewable Energy. 34, 421- 424.

Thomas, L., Larroche, C., \& Pandey, A. (2013). Current developments in solid-state fermentation. Biochemical Engineering Journal. 81, $146-161$.

Wang, H., Zhai, L., \& Geng, A. (2020). Enhanced cellulase and reducing sugar production by a new mutant strain Trichoderma harzianum EUA20. Journal of Bioscience Bioengineering. 129, 242-249. 